\title{
Low density of ghrelin cells in the oxyntic mucosa correlated to slow gastric emptying in patients with type 1 diabetes
}

\author{
M. EL-SALHY and J. RAUMA
}

\begin{abstract}
Section for Gastroenterology, Institute of Internal Medicine, University of Bergen, N-5021 Bergen; Section for Gastroenterology, Medicine Clinic, Stord Helse-Fonna Hospital, N-5409 Stord, Norway
\end{abstract}

Received June 22, 2009; Accepted September 8, 2009

DOI: 10.3892/mmr_00000188

\begin{abstract}
Ghrelin is a peptide hormone that has been isolated from the stomach and localized to endocrine cells in the oxyntic mucosa. Ghrelin acts synergistically with GH-releasing hormone and increases appetite and feeding. It also accelerates gastric and small intestinal motility in rodents. Patients with diabetes suffer from slow gastric emptying, giving rise to nausea and vomiting. The present study was undertaken to establish the possible role of ghrelin in slow gastric emptying observed in patients with longstanding type 1 diabetes, and to correlate the results with the metabolic status of these patients. Eleven patients with type 1 diabetes along with 10 and 15 healthy volunteers as controls underwent gastrointestinal endoscopy/biopsy or gastric scintigraphy. Gastric emptying in patients and controls was measured by scintigraphy. Sections from biopsies of the oxyntic mucosa and duodenum were immunostained for ghrelin with the avidin-biotin complex method. The density of the cells was quantified with computerized image analysis. Both the lag phase and halfemptying time $\left(\mathrm{T}_{50}\right)$ were higher in patients with diabetes than in healthy volunteers. The $\mathrm{T}_{50}$ was correlated with the blood glucose level. The density of ghrelin-immunoreactive cells in the oxyntic mucosa of patients with diabetes was significantly reduced compared to the healthy controls. Ghrelin cell density was correlated with both the lag phase and $\mathrm{T}_{50}$, as well as with blood glucose level. The present finding of reduced density of ghrelin cells in patients with type 1 diabetes, which was well correlated with gastric emptying, indicates the possible role of ghrelin in the pathophysiology of gastroparesis observed in diabetes.
\end{abstract}

\section{Introduction}

Ghrelin is a peptide hormone that has been isolated from the stomach (1). It originates mostly from endocrine cells in the

Correspondence to: Professor Magdy El-Salhy, Section for Gastroenterology, Medicine Clinic, Stord Helse-Fonna Hospital, Box 4000, N-5409 Stord, Norway

E-mail: magdy.el-salhy@helse-fonna.no

Key words: diabetes, gastric emptying, ghrelin, oxyntic mucosa oxyntic mucosa of the stomach, though small amounts have also been found in the small intestine and arcuate nucleus of the hypothalamus $(1,2)$. Ghrelin has several functions, the best known of which is its growth hormone $(\mathrm{GH})$-releasing effect in the pituitary, where it acts synergistically with GH-releasing hormone (1,3). Ghrelin also increases appetite and feeding $(4,5)$, and stimulates the orexigenic pathways through neuropeptide Y (NPY) and agouti-related peptide (AgRP) neurons in the arcuate nucleus of the hypothalamus $(6,7)$. Additionally, ghrelin has been found to accelerate gastric and small intestinal motility in rodents $(8,9)$.

Patients with diabetes suffer from slow gastric emptying, which gives rise to nausea and vomiting and worsens their metabolic control (10-12). As ghrelin appears to play an important role in regulating gastric motility, the present study was undertaken to establish the possible role of ghrelin in slow gastric emptying observed in diabetes patients. To this end, the density of ghrelin cells was estimated and correlated to gastric emptying and the metabolic status of patients with longstanding type 1 diabetes.

\section{Materials and methods}

Patients and healthy subjects. Eleven patients with type 1 diabetes (9 women and 2 men) with a mean age of 45 years (range 28-78 years) participated in the study. Clinical data are summarized in Table I. All patients underwent hydrogen breath and ${ }^{75} \mathrm{Se}$-homocholic taurine-conjugated bile acid (SeHCAT) tests. Both tests were normal in all patients, excluding smallbowel bacterial overgrowth and bile acid malabsorption.

Ten healthy volunteers without gastrointestinal complaints ( 8 women and 2 men; mean age 32 years, range 22-50 years) served as controls for gastrointestinal endoscopy and biopsy. Another 15 healthy volunteers without any gastrointestinal complaints (10 women and 5 men; mean age 47 years, range 25-65 years) served as controls for gastric scintigraphy. The investigation was approved by the local committee on ethics.

Scintigraphic measurements of gastric emptying. Scintigraphic measurement of gastric emptying in diabetic patients and controls was performed as previously described (13). Briefly, after overnight fasting, gastric emptying of solid food was carried out after the subjects had ingested a standard meal consisting of an omelette $(311 \mathrm{kcal})$ and a $150-\mathrm{ml}$ soft drink (70 kcal). The omelette contained $15 \mathrm{MBq}{ }^{99}$-Tc-labelled 


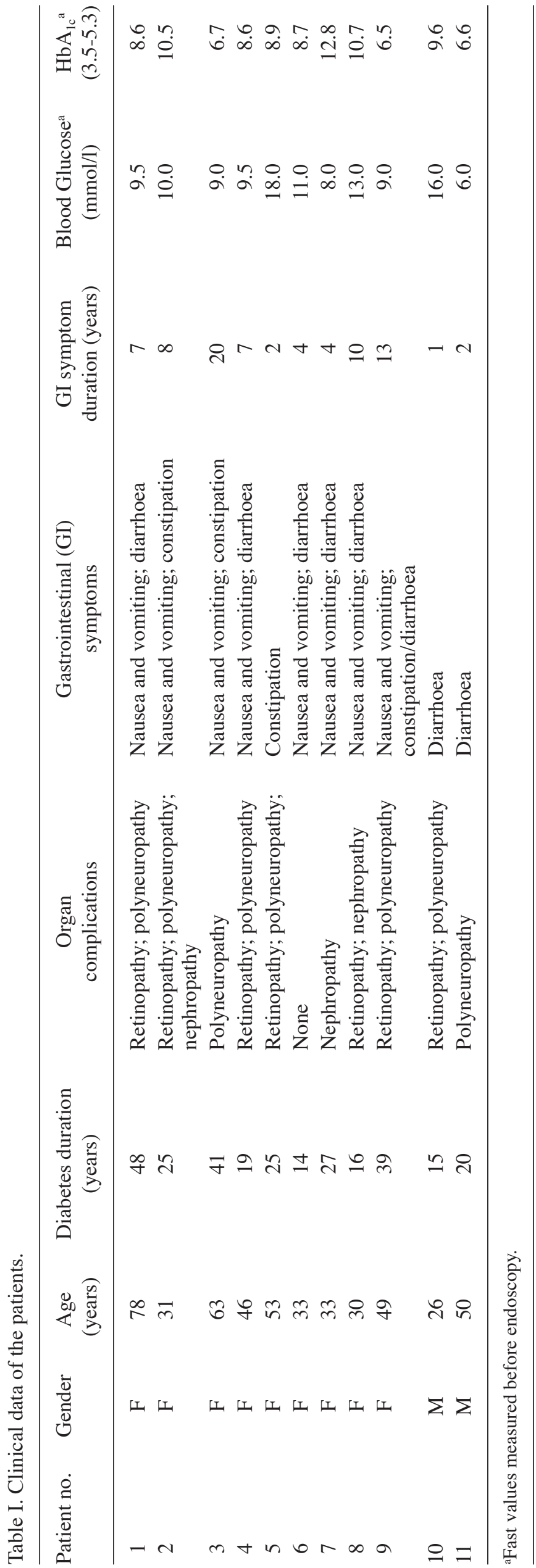

macroaggregated albumin (Pulmonate; Amersham Int., Little Chalfont, UK). The meal was eaten within $10 \mathrm{~min}$ and measurements were taken immediately after ingestion, with the subject seated in an upright position and the Gamma camera in an anterior position. The region of interest corresponding to the stomach was outlined to determine the gastric count for each frame. Data were acquired for $220 \mathrm{~min}$, $60 \mathrm{sec} /$ frame, at 5 -min intervals for $30 \mathrm{~min}$, and thereafter at 10-min intervals. After correction for background scatter and isotope decay, the lag phase and half-emptying time $\left(\mathrm{T}_{50}\right)$ were calculated.

Gastrointestinal endoscopy. After at least $6 \mathrm{~h}$ of fasting, a gastroduodenal endoscopy was performed in the patients and controls. During the endoscopy procedure, two or three biopsies were obtained from the corpus (major curvature) and pars decendens duodeni (distal to papilla of Vateri). In addition, biopsies were taken from the antrum and used in the camplyobacter-like organism (CLO) test for Helicobacter pylori.

Histopathology and immunohistochemistry. Biopsies were fixed in $4 \%$ buffered paraformaldehyde overnight, embedded in paraffin and cut into $5 \mu \mathrm{m}$-thick sections. The sections were stained by H\&E and immunostained with the avidinbiotin complex (ABC) method (Dako Cyotmation, Glostrup, Denmark) as previously described in detail (14). The primary antiserum used was anti-ghrelin (polyclonal, code no. 00182, dilution 1:1600, Phoneix Pharmaceuticals, Belmont, CA, USA). The sections were counterstained slightly with haematoxylin. Negative controls included replacing the primary antiserum with $1 \%$ bovine albumin and pre-incubating the diluted antiserum with excessive ghrelin (50 $\mu \mathrm{g} / \mathrm{ml}$, NeoMPS, Strasbourg, France) at $4^{\circ} \mathrm{C}$ overnight.

Computerized image analysis. Computerized image analysis was performed using the Leica Quantimet $600 \mathrm{MC}$ image processing and analysis system (Leica, Cambridge, UK) linked to an Olympus microscope (type BX50). The system used the QWin program (version 2.6), Leica's Windows-based image analysis tool kit, and included QUIPS (version 2.6), an interactive programming system. Using x20 objectives, each pixel of the computer monitor corresponded to $0.173 \mu \mathrm{m}$, and the frame (field) represented an area of $5436 \mu \mathrm{m}^{2}$. The number of ghrelin-immunoreactive cells and the area of the epithelial cells were measured. Using QUIPS, an automated standard sequence analysis operation was created as previously described in detail (15). Briefly, the number of immunoreactive cells was counted using the field measurements. The areas of the epithelial cells were measured using a threshold setting. The data from each field were tabulated and the number of cells/ $\mathrm{mm}^{3}$ was computed and statistically analysed automatically. Measurements were taken in 10 randomly selected fields in the stomach and duodenum of each individual using an x 20 objective.

Statistical analysis. Comparison between patients and controls was performed with the Wilcoxon non-parametric test, and correlation with the Spearman non-parametric test. P-values of $<0.05$ were considered significant. 


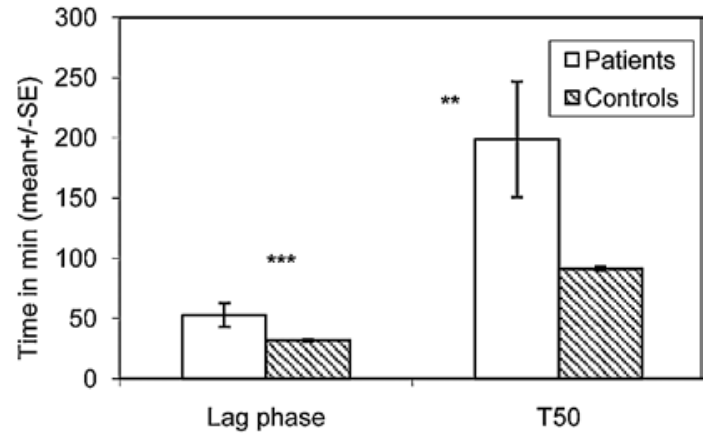

Figure 1. Gastric emptying in patients with diabetes and in controls.

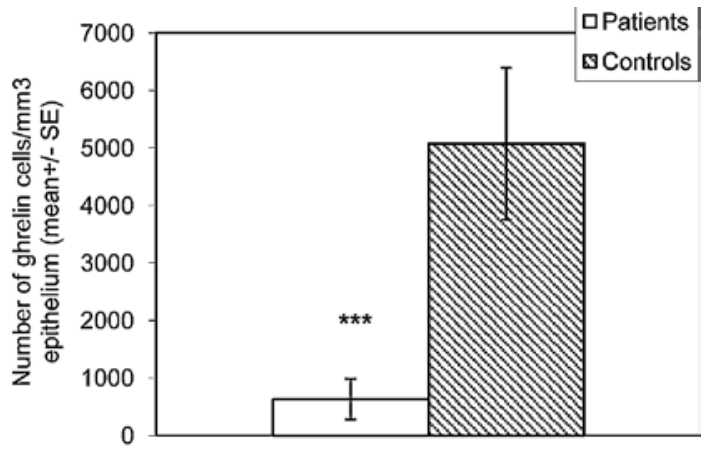

Figure 2. Density of gherlin-immunoreactive cells in the oxyntic mucosa of the stomach in patients with diabetes and in controls.

\section{Results}

Scintigraphic measurements of gastric emptying. The results of gastric emptying are presented in Fig. 1. Both the lag phase and $\mathrm{T}_{50}$ were higher in patients with diabetes than in the healthy volunteers $\left(\mathrm{P}<0.001\right.$ and $<0.001$, respectively). The $\mathrm{T}_{50}$ was correlated with the blood glucose level $(\mathrm{P}=0.003 ; \mathrm{r}=0.8)$, whereras the lag phase was not $(\mathrm{P}=0.4 ; \mathrm{r}=3)$. Neither the lag phase nor the $\mathrm{T}_{50}$ was correlated with $\mathrm{HbA}_{1 \mathrm{c}}$.

Gastrointestinal endoscopy. The stomach and duodenum of the patients and the healthy volunteers were macroscopically normal. One of the patients and one of the healthy volunteers had a positive CLO test result, indicating infection with Helicobacter pylori.

Histopathology and immunohistochemistry. Histopathological examination of the gastric and duodenal biopsies from patients and healthy volunteers revealed normal histology, thus excluding celiac disease. Ghrelin-immuoreactive cells were found in the stomach oxyntic mucosa and among the epithelial cells of the duodenum. In the duodenum, ghrelin cells were few and unevenly distributed, which did not allow for reliable quantification. The cells occurred mostly in the crypts, and were round, flask-shaped or triangular (Fig. 2).

Computerized image analysis. The density of ghrelinimmunoreactive cells in the oxyntic mucosa of patients with diabetes was significantly reduced $(\mathrm{P}=0.0007)$ compared to the healthy controls (Fig. 3). Ghrelin cell density in the
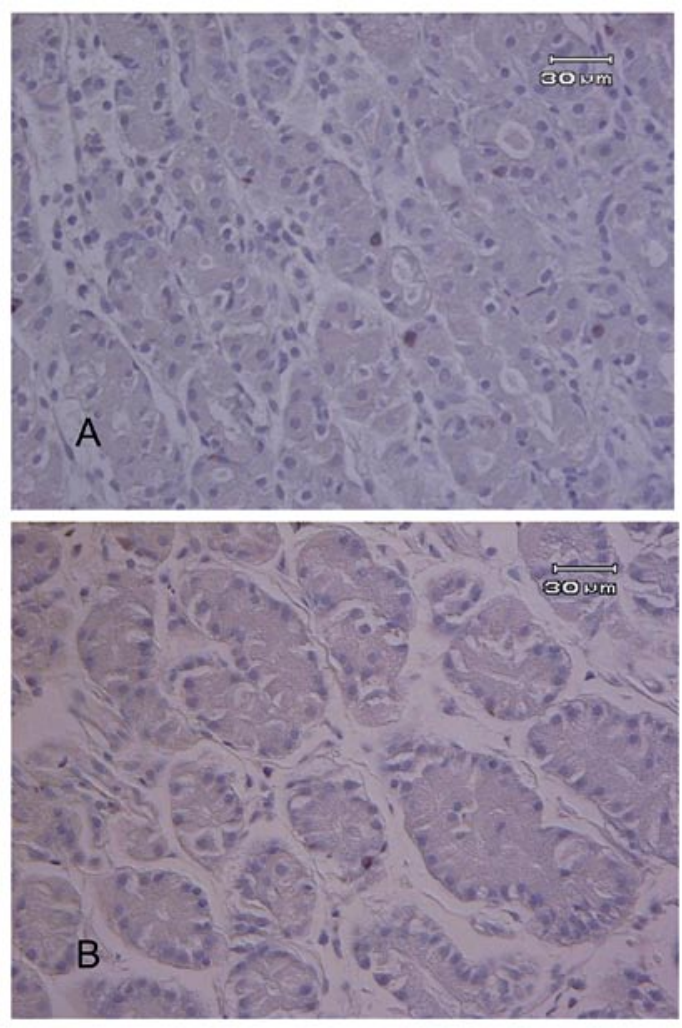

Figure 3. Gherlin-immunoreactive cells in the oxyntic mucosa of (A) a control subject and (B) a patient with diabetes.

oxyntic mucosa correlated with lag phase and the $\mathrm{T}_{50}(\mathrm{P}=0.01$ and $\mathrm{P}=0.007 ; \mathrm{r}=-0.7$ and $\mathrm{r}=-0.8$, respectively) and with blood glucose level $(\mathrm{P}=0.003 ; \mathrm{r}=-0.8)$.

\section{Discussion}

The present finding that ghrelin cell density in the oxyntic mucosa was reduced in patients with longstanding type 1 diabetes is in agreement with an earlier observation in rats with streptozotocin-induced diabetes and mouse models of human type 1 diabetes (16,17). The present investigation further demonstrated that gastric emptying is inversely correlated with the density of ghrelin cells in the oxyntic mucosa. As ghrelin has been shown to stimulate gastric motility, it is conceivable that the paucity of ghrelin cells in the oxyntic mucosa is one of the factors causing slow gastric emptying in patients with type 1 diabetes. This assumption is also supported by the close correlation found between gastric emptying and ghrelin cell density. Furthermore, ghrelin injection given as a bolus dose at the end of a meal has been found to accelerate gastric emptying in patients with diabetes and gastroparesis $(18,19)$. Although ghrelin cell density was reduced in patients with diabetes type 1, it was unclear whether these cells compensated for their paucity by increasing ghrelin synthesis and release. Further studies are therefore required, in which the concentrations of total and active ghrelin in tissue extracts and plasma are determined. It is worth noting that plasma levels of active ghrelin in obese patients with type 2 diabetes have been found to be low, and that the ghrelin cell density in the oxyntic mucosa of animal models of human diabetes has been reported to be reduced $(17,20)$. 
The present study showed a close correlation between ghrelin cell density in the oxyntic mucosa and glucose level in patients with longstanding type 1 diabetes. As ghrelin is known to increase appetite and feeding, the paucity of ghrelin cells in the patients investigated might be induced by hyperglycaemia over a long period.

Ghrelin shares several structural similarities with motilin and acts on motilin receptors (21-23). The motilin agonist erythromycin has been successfully used in the treatment of gastroparesis in patients with diabetes (11). The present findings suggest that ghrelin might have a therapeutic role in patients with diabetes and gastroparesis.

\section{Acknowledgements}

This study was supported by grants from Helse-Fonna.

\section{References}

1. Kojima M, Hosoda H, Date J, Nakazato M, Matsuo H and Kangawa K: Ghrelin is growth-hormone-releasing acetylated peptide from stomach. Nature 402: 656-660, 1999.

2. Date Y, Kojima M, Hosoda H, Sawaguchi A, Mondal MS, Suganuma T, Matsukura S, Kangawa $\mathrm{K}$ and Nakazato $\mathrm{M}$ : Ghrelin, a novel growth hormone-releasing acetylated peptide, is synthesized in a distinct endocrine cell type in the gastrointestinal tracts of rats and humans. Endocrinology 141: 4255-4261, 2000.

3. Hataya Y, Akamizu T, Takaya K, Ariyasu N, Sajo M, Moriyama K, Shimatsu A, Kojima M, Kangawa K and Nakato K: A low dose of ghrelin stimulates growth hormone $(\mathrm{GH})$ release synergistically with GH-releasing hormone in humans. J Clin Endocrinol Metab 86: 4552-4555, 2001.

4. Ghatei MA and Bloom SR: Ghrelin enhances appetite and increases food intake in humans. J Clin Endocrinol Metab 86: 5992-5995, 2000

5. Wren AM, Seal LJ, Cohen MA, Brynes A, Frost GS, Murphy KG, Dhillo LO and Chatei MA: Ghrelin enhances appetite and increases food intake in humans. J Clin Endocrinol Metab 86: 5992-5995, 2001.

6. Hosoda H, Kojima M and Kangawa K: Ghrelin and the regulation of food intake and energy balance. Mol Interv 8: 494-503, 2002.

7. Cowley MA and Grove KL: Ghrelin - satisfying a hunger for the mechanism. Endocrinology 145: 2604-2606, 2004.

8. Fujino K, Inui A, Asakawa A, Kihara N, Fujimura $M$ and Fujimiya M: Ghrelin induces fasted motor activity of the gastrointestinal tract in conscious fed rats. J Physiol 550: 227-240, 2003.
9. Masuda Y, Tanaka T, Inomata N, Ohmura N, Tanaka S, Itoh Z, Hosisa H, Kojima $M$ and Kangawa K: Ghrelin stimulates gastric acid secretion and motility in rats. Biochem Biophys Res Commun 276: 905-908, 2000.

10. El-Salhy M: The possible role of the gut neuroendocrine system in diabetes gastroenteropathy. Histol Histopathol 4: 1153-1161, 2002.

11. El-Salhy M: Gut neuroendocrine system in diabetes gastroenteropathy: possible role in pathophysiology and clinical implications. In: Focus on Diabetes Mellitus Research. Ashley M. Ford (ed). Nova Science Publishers Inc., New York, pp79-102, 2006.

12. Koch KL: Diabetic gastropathy. Gastric neuromuscular dysfunction in diabetes mellitus. A review of symptoms, pathophysiology and treatment. Dig Dis Sci 44: 1061-1075, 1999.

13. El-Salhy M and Sitohy B: Abnormal gastrointestinal endocrine cells in patients with diabetes type 1: relation to gastric emptying and myoelectrical activity. Scand J Gastroenterol 36: 1162-1169, 2001.

14. El-Salhy M, Stenling R and Grimelius L: Peptidergic innervation and endocrine cells in the human liver. Scand J Gastroenterol 28: 809-815, 1993.

15. El-Salhy M, Sandström O, Näsström E, Mustajbasic M and Zachrisson S: Application of computer image analysis in endocrine cell quantification. J Histochem 29: 249-255, 1997.

16. Masaoka T, Suzuki H, Hosoda H, Ota T, Minegishi Y, Nagata H, Kangawa $\mathrm{K}$ and Ishii $\mathrm{H}$ : Enhanced plasma ghrelin levels in rats with streptozotocin-induced diabetes. FEBS Lett 541: 64-68, 2003.

17. Rauma J, Spångéus A and El-Salhy M: Ghrelin cell density in the gastrointestinal tracts of animal models of type 1 and type 2 diabetes. Histol Histopathol 21: 1-5, 2006.

18. Binn M, Albert C, Gougeon A, Maereki H, Coulie B, Lemoyne M, Rabasa-Lhoret R, Tomasetto C and Poitras P: Ghrelin gastrokinetic action in patients with neurogenic gastroparesis. Peptides 27: 1603-1606, 2006.

19. Murray CDR, Martin NM, Patterson M, Taylor SA, Ghatei MA, Kamm MA, Johnston C, Bloom SR and Emmanuel AV: Ghrelin enhances gastric emptying in diabetic gastroparesis: a double blind, placebo controlled, crossover study. Gut 54: 1693-1698, 2005.

20. Katuski A, Urakawa H and Gabazza EC: Circulating levels of active ghrelin is associated with abdominal adiposity, hyperinsulinaemia and insulin resistance in patients with type 2 diabetes mellitus. Euro J Endocrionol 151: 573-577, 2004.

21. Del Rincon JP, Thorner MO and Gaylinn BD: Motilin-related peptide and ghrelin: lessons from molecular techniques, peptide chemistry and receptor biology. Gastroenterology 120: 588-589, 2001.

22. Folwaczny C, Chang JK and Tschöp M: Ghrelin and motilin: two sides of one coin? Euro J Endocrinol 144: 1-3, 2001.

23. Tomasetto C, Karam SM, Ribieras S, Masson R, Lefebvr O, Staub A, Alexander G, Chenard MP and Rio MC: Identification and characterization of novel gastric peptide hormone: the motilin-related peptide. Gastroenterology 119: 395-405, 2000. 